\title{
ROLL OF COMMISSIONED OFFICERS IN THE MEDICAL SERVICES OF THE BRITISH ARMY, 1660-1960
}

The Wellcome Institute of the History of Medicine is shortly to publish in two volumes the first complete Roll of the Commissioned Medical Officers in the British Army. The first volume consists of a reprint of Johnston's Roll, which has entries for all the officers in the Army Medical Services from the accession of George II (1727) until the formation of the Royal Army Medical Corps, 23 June 1898. Only 250 copies of this Roll were originally printed during the First World War (1917), and it is now so rare that it is often difficult to find even in large libraries.

In 1925 one of Colonel Johnston's collaborators, Colonel Peterkin, supplemented the Roll with a similar list of medical officers serving between 1660 and 1727 . This has become even more difficult to find, and is therefore reprinted as a preliminary to Johnston's Roll.

Volume II of the work, which is much more extensive, consists of a complete list of the officers from the formation of the Royal Army Medical Corps until 1960. This has been compiled under the command of Lieutenant-General Sir Robert Drew, K.C.B., and he appears as the General Editor. These two volumes provide the basic reference work for any historical studies on the medical services of the British Army.

The two-volume work will be available in the autumn from the Wellcome Institute of the History of Medicine, 183 Euston Road, London, N.W.1.

\section{COMMEMORATION OF HERMAN BOERHAAVE}

On 31 December 1968 it will be the 300th anniversary of the birth of Herman Boerhaave, professor of medicine, botany and chemistry in the University of Leyden from 1709-1738. A celebration to commemorate that event will be organized on 15 and 16 November 1968. A special Committee under the Chairmanship of Prof. Dr. J. Dankmeijer has been charged with the preparation of the celebration, which will be sponsored by several learned societies.

The Museum of History of Medicine and Science (Director Dr. Maria Rooseboom) has organized an exhibition on Herman Boerhaave and his work, which will be open from 13 June to 1 December 1968. A special catalogue of the collection will be available.

On the occasion of the celebration a special commemorative medal will be struck.

The official Commemoration Session will take place on 15 November. It will be dedicated to the general importance of Herman Boerhaave, especially in the light of seventeenth-century philosophy, and his influence upon medical sciences. On the following day, a symposium on 'Boerhaave and his Time' has been planned. Several scientists have been invited to contribute a lecture on various subjects concerning the personality of Herman Boerhaave and his relations to seventeenth- and eighteenthcentury medicine or science.

The papers read will be printed in a special commemoration volume edited by Prof. Dr. G. Lindeboom (Amsterdam) and published by E. J. Brill (Leiden) in the Analecta Boerhaaviana Series. 


\section{News, Notes and Queries}

The eight Academical 'Orationes' of Herman Boerhaave will be edited in an English translation by Prof. Dr. A. G. H. Bachrach (Leiden) in the series Publications from the Sir Thomas Browne Institute in Leiden.

\section{AMERICAN INSTITUTE OF THE HISTORY OF PHARMACY}

The Edward Kremers Award for 1968 will be awarded to Dr. Martin Levey. This award was established by the American Institute of the History of Pharmacy to recognize distinguished writing in pharmaceutical history by an American scholar. It was established in honour of the late Edward Kremers, a distinguished figure in American Pharmaceutical Education who encouraged the study of pharmaceutical history and was active in the establishment of the American Institute of the History of Pharmacy. Selection of the recipient for the Kremers Award is made by the Awards Committee of the Institute.

Dr. Martin Levey is professor of the history of science at State University of New York at Albany. He has been a member of the Institute for Advanced Study at Princeton and a member of the faculty of Yale University. He is a chemist, historian of science, and a student of ancient languages. His many publications include Chemistry and Chemical Technology in Ancient Mesopotamia (1959) and Medieval Arabic Book Making and Its Relation to Early Chemistry and Pharmacology (1962). The Awards Committee of the Institute made special reference to his The Medical Formulary of Al-Kindi (1966) and The Medical Formulary of Al-Samargandi (1967).

\section{JOURNAL OF THE HISTORY OF BIOLOGY}

The first issue of this new journal has just appeared (spring, 1968) from Harvard University Press, and is to be published twice a year. The Editor is Professor Everett Mendelsohn (Holyoke Center 838, Cambridge, Massachusetts 02138) and he is assisted by a distinguished Editorial Board. The well-produced octavo of 161 pages contains a number of articles of great interest to medical historians, including a study of 'Sherrington's concept of integrative action' by Judith P. Swazey, and 'First steps in Claude Bernard's discovery of the glycogenic function of the liver' by M. D. Grmek, the latter being the text of a lecture which Professor Grmek gave recently at Harvard University. 